Reprod. Nutr. Dévelop., 1982, 22 (3), 575-581.

\title{
Dietary fiber and cholesterol and bile acid metabolisms in axenic (germfree) and holoxenic (conventional) rats. II. Effect of pectin
}

\author{
E. SACQUET, C. LEPRINCE, M. RIOTTOT
}

Laboratoire des Animaux sans Germes, C.N.R.S. I.N.R.A., 78350 Jouy-en-Josas, France

Summary. Axenic and holoxenic rats were fed with a semi-synthetic diet containing 5 p. 100 pectin as the only fiber. Although the microbial flora of the digestive tract converted most of the bile acids in holoxenic rats, it hardly changed the other characteristics of cholesterol and bile acid metabolisms, except intestinal bile salt pools which were much larger in the axenic rats.

When the pectin-containing and pectin-free diets were compared, it appeared that the former diet increased cecal weight, especially in axenic rats, but slightly modified cholesterol and bile acid metabolisms. However, the values of some characteristics of those metabolisms varied individually in the holoxenic rat fed with the pectin-containing diet, while they were very homogeneous in the other groups. This heterogeneity might result from pectin-digestive tract microbial flora interactions which would vary among individuals.

\section{Introduction.}

Although most authors agree that pectin intake decreases cholesterolemia and increases fecal elimination of cholesterol and sometimes of bile acids (Leveille and Sauberlich, 1966 ; Mathé et al., 1977 ; Kelley and Tsai, 1978 ; Reddy, Watanabe and Sheinfil, 1980), they disagree on some points. Reddy, Watanabe and Sheinfil used a very high pectin level (15 p. 100) that doubled fecal elimination of cholesterol and bile acids but also considerably decreased ponderal weight. With more physiological doses (5 p. 100), Kelley and Tsai observed a $20 \mathrm{p}$. 100 decrease in cholesterol absorption. With the same dietary pectin level, Mathé et al. obtained a decrease in plasma cholesterol concentration and a moderate increase of total cholesterol synthesis. But they also noticed a decline in hepatic cholesterol not reported by the other authors and, conversely, no decrease in dietary cholesterol absorption or increase in fecal bile acid excretion. Vahouny et al. (1980) found that pectin decreased cholesterol absorption and that it acted by binding the cholesterol and the bile salts.

In the present study, as in the previous work on wheat bran (Sacquet et al., 1982), we wished to determine if the microbial flora of the digestive tract is 
implicated in the effect of pectin on cholesterol and bile acid metabolisms. We studied the effects in axenic (GF) and holoxenic (CV) rats of a diet containing $5 \mathrm{p}$. 100 pectin (P) as the only fiber. The results in GFP and CVP rats have been compared to those of the preceding study.

\section{Material and methods.}

As in the previous experiment, the basic diet included : saccharose $62.7 \mathrm{~g}$, casein $22.2 \mathrm{~g}$, corn oil $9.7 \mathrm{~g}$, mineral salts $4.9 \mathrm{~g}$, cholesterol $97 \mathrm{mg}$, vitamins QS. To this diet we added pectin (5 p. 100 of the weight of the diet). We used highly esterified (73.6 p. 100) apple pectin (AF) made by Unipectine, France, and closely approximating the lemon pectin defined by American standards. The diet was put into plastic, vacuum-sealed bags and sterilized by gamma irradiation $(40 \mathrm{kGy})$. When the rats were given their daily ration, we added to it $20 \mathrm{p} .100$ of its weight in water.

The rest of the experimental protocol, identical to that of the previous experiment, is recalled here briefly.

We used axenic (GF) and holoxenic (CV) male Fischer rats in two experiments ; one established an isotopic equilibrium of $\left(4-{ }^{14} \mathrm{C}\right)$-cholesterol and the other measured the cholesterol absorption coefficient.

The method of isotopic cholesterol equilibrium was employed for technical reasons. When isotopic equilibrium is reached, hepatic and plasma cholesterol and all the chemical species of bile acids have the same specific activity, making it easy to determine them. After hot ethanol extraction in a Kumagawa apparatus, the neutral and acid sterols were separated by the method of Grundy, Ahrens and Miettinen (1965). Fecal bile acid composition was determined by thin-layer chromatography on silicagel $G$ with a mobile phase of chloroformacetone-methanol (70/25/5). Hepatic cholesterol was determined by the method of Liebermann. Fecal cholesterol was determined using thin-layer chromatography to separate the cholesterol, then assaying it by gas-liquid chromatography on a $2-\mathrm{m}$ long pyrex column containing 3 p. 100 OV17 and 3 p. 100 QF1 absorbed in equal parts on chromosorb WHMD S 80/100 mesh at $225{ }^{\circ} \mathrm{C}$.

The cholesterol absorption coefficient was measured using the method of Crouse and Grundy (1978). Another group of rats was put in experimental conditions similar to those of the isotopic equilibrium group and, at the end of a 3 -week period, was given a constant daily dose of $\left(1,2-{ }^{3} \mathrm{H}\right)$-cholesterol and of (4$\left.{ }^{14} \mathrm{C}\right)$ - $\beta$-sitosterol in the diet. The absorption coefficient was calculated using the formula

$$
A C=100\left(1-\frac{{ }^{3} \mathrm{H} /{ }^{14} \mathrm{C} \text { excreted }}{{ }^{3} \mathrm{H} /{ }^{14} \mathrm{C} \text { ingested }}\right) \text {. }
$$

Statistical methods. - The GFP and CVP rats were compared using Student's ttest. When comparing the rats of this study to those of the previous experiment which received no fiber, we employed two-factor analysis of variance and determined the effect of microbial flora, pectin and their interactions. 


\section{Results.}

As in all former experiments, the axenic rats ingested slightly less of the diet than the holoxenics (table 1). Their cecum was much more voluminous and richer in water. Their growth and body weight at the end of the experiment were similar to those of the holoxenics. When the weight of the cecum, which represented a dead weight and is abnormally higher in axenic rats, was deducted, the body weight of the axenics was less than that of the holoxenics (GFP $=276 \mathrm{~g} ;$ CVP $=292 \mathrm{~g})$. The coefficient of digestibility could not be determined in the axenic rats ; that of the holoxenics was very high, suggesting that they digested the pectin well.

The values of the cholesterol absorption coefficient stabilized from day 4 (fig.1); they were slightly higher in holoxenics (table 2). The concentrations of

TABLE 1

Age, body and cecal weights, cecal water content, feed intake and dry matter digestibility in axenic (GFP) and holoxenic (CVP) rats fed a pectin-containing diet. Mean \pm SDM of 4 rats

\begin{tabular}{|c|c|c|}
\hline Groups & GFP & CVP \\
\hline 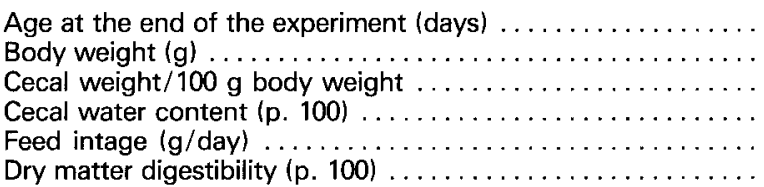 & $\begin{aligned} & 123 \\
& 304 \pm 5.6 \\
& 9.3 \pm 0.20\left(^{*}\right) \\
& 83.1 \pm 0.21\left(^{*}\right) \\
& 12.6 \pm 0.6\end{aligned}$ & $\begin{array}{l}127 \\
296 \pm 2.1 \\
1.3 \pm 0.12\left(^{*}\right) \\
79.3+0.14\left(^{*}\right) \\
13.9 \pm 0.21 \\
94.5 \pm 0.2\end{array}$ \\
\hline
\end{tabular}

$\left.{ }^{*}\right)$ Statistically different

TABLE 2

Absorption coefficient and fecal elimination of cholesterol, fecal bile acid excretion and intestinal pools in axenic and and holoxenic rats fed a pectin-containing diet. Mean \pm SDM of 4 rats

\begin{tabular}{|c|c|c|c|c|}
\hline \multirow{2}{*}{$\frac{\text { Groups }}{\text { Absorption coefficient of cholesterol }(p .100):}$} & \multicolumn{2}{|r|}{ GFP } & \multicolumn{2}{|r|}{ CVP } \\
\hline & & & & \\
\hline 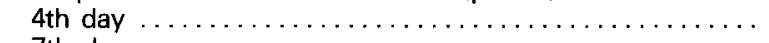 & 65.4 & $\pm 0.45\left(^{*}\right)$ & 68.3 & $\pm 0.3\left({ }^{*}\right)$ \\
\hline 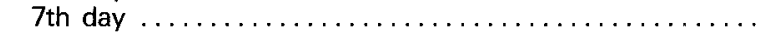 & 64.9 & $\pm 0.8 \quad\left(^{*}\right)$ & 69.0 & $\pm 1.6\left({ }^{*}\right)$ \\
\hline Cholesterol concentration in plasma $(\mathrm{mg} / 100 \mathrm{ml}) \ldots$ & 93 & \pm 5.0 & 94 & \pm 1.3 \\
\hline $\begin{array}{c}\text { Cholesterol concentration in liver }(\mathrm{mg} / 100 \mathrm{ml} \text { fresh liver } \\
\text { weight) } \ldots \ldots \ldots \ldots \ldots \ldots \ldots \ldots \ldots \ldots \ldots \ldots \ldots \ldots \ldots \ldots \ldots \ldots \ldots \ldots\end{array}$ & 300 & \pm 8.0 & 296 & \pm 13 \\
\hline $\begin{array}{l}\text { Fecal elimination of cholesterol } \\
\mathrm{mg} / 100 \mathrm{~g} \text { body weight } / \text { day } \ldots \ldots \ldots \ldots \ldots \ldots \ldots \ldots \ldots \ldots \\
\mu \text { moles } / 100 \mathrm{~g} \text { body weight } / \text { day } \ldots \ldots \ldots \ldots \ldots \ldots \ldots\end{array}$ & $\begin{array}{l}2.17 \\
5.6\end{array}$ & $\begin{array}{l} \pm 0.12 \\
\pm 0.3\end{array}$ & $\begin{array}{l}2.71 \\
7.0\end{array}$ & $\begin{array}{l} \pm 0.46 \\
\pm 1.2\end{array}$ \\
\hline $\begin{array}{l}\text { Fecal bile acid excretion } \\
\qquad(\mu \text { moles } / 100 \mathrm{~g} \text { body weight } / \text { day }) \ldots \ldots \ldots \ldots \ldots \ldots\end{array}$ & 11.2 & \pm 0.6 & 12.1 & \pm 0.3 \\
\hline $\begin{array}{l}\text { Total fecal elimination of sterols } \\
(\mu \text { moles } / 100 \mathrm{~g} \text { body weight } / \text { day }) \ldots \ldots\end{array}$ & 16.8 & \pm 1.0 & 19.1 & \pm 1.1 \\
\hline $\begin{array}{l}\text { Bile acid content }(\mu \text { moles } / 100 \mathrm{~g} \text { body weight }) \\
\text { in the small intestine } \ldots \ldots \ldots \ldots \ldots \ldots \ldots \ldots \ldots \ldots \ldots \ldots \ldots \\
\text { in cecum and large intestine } \ldots \ldots \ldots \ldots \ldots \ldots \ldots \ldots \ldots\end{array}$ & $\begin{array}{l}44.9 \\
42.4\end{array}$ & $\begin{array}{l} \pm 1.7\left(^{*}\right) \\
\pm 2.4(*)\end{array}$ & $\begin{array}{l}21.3 \\
14.4\end{array}$ & $\begin{array}{l} \pm 1.5\left(^{*}\right) \\
\pm 2.5\left({ }^{*}\right)\end{array}$ \\
\hline
\end{tabular}

$\left.{ }^{*}\right)$ Statistically different 


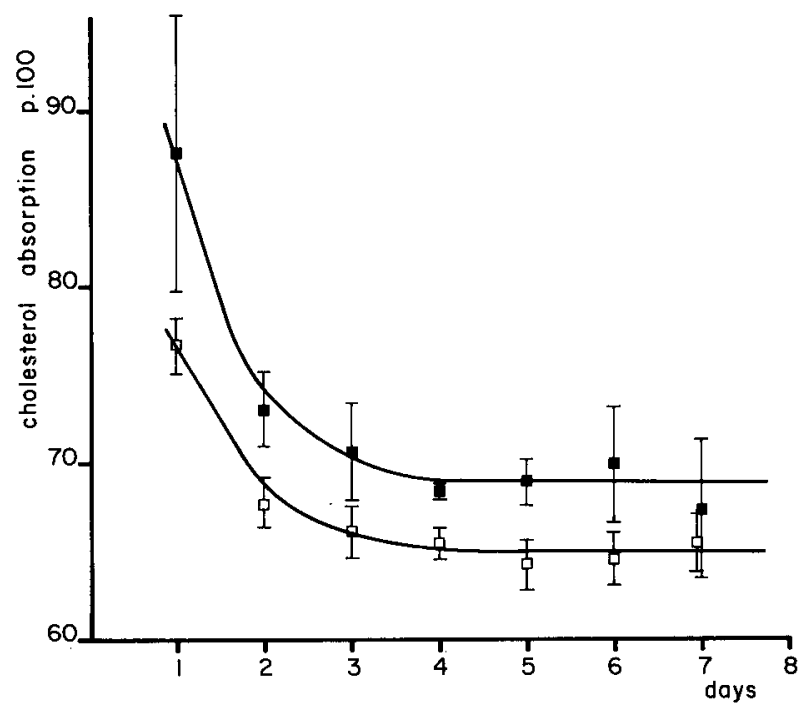

FIG. 1. - Cholesterol absorption coefficient values during the days after marker intake in axenic ( $\square$ ) and holoxenic (D) rats. Mean $\pm S D$.

cholesterol in the plasma and liver were similar. The values of fecal cholesterol elimination were very homogeneous in the axenic group and, on the contrary, very heterogeneous in the holoxenic one; this resulted in mean values that were not significantly different in the two groups. Fecal bile acid excretion and total sterol elimination were not significantly different in the two groups. On the contrary, the intestinal bile salt pools were very divergent, being much higher in axenics than in holoxenics. The pool of the cecum and the large intestine was particularly high and became equal to that of the small intestine in GFP rats.

Although many characteristics of this metabolism showed similar values in both groups, the microbial flora of the CVP rats metabolized a very large part of the primary bile acids, as shown in the comparison of fecal bile acids in table 3 . Few cholic and $\beta$-muricholic acids remained in CVP rats. The fecal bile acid composition of those rats showed little individual variation, except for $\omega$ muricholic and hyodeoxycholic acids, the proportions of which showed individual complementary variation. Also, in 3 out of 4 individuals, a large proportion (75, 75 and $80 \mathrm{p} .100$ ) of the cholesterol was converted into coprostanol, while in the 4 th rat that conversion was low (15 p. 100).

\section{Discussion.}

By comparing these results with those of the preceding study (Sacquet et al., 1982) using axenic and holoxenic rats given the same basic fiber-free diet (GFO, CVO rats) or a 10 p. 100 bran diet (GFB, CVB rats), we estimated the role 
TABLE 3

Per cent average composition of fecal bile acids in axenic (GFP) and holoxenic rats (CVP) fed the pectin-containing diet. Mean \pm SDM of 4 rats

\begin{tabular}{|c|c|c|c|}
\hline & Groups of rats & GFP & CVP \\
\hline \multicolumn{2}{|r|}{ Acids } & p. 100 & p. 100 \\
\hline \multirow{6}{*}{\multicolumn{2}{|c|}{ 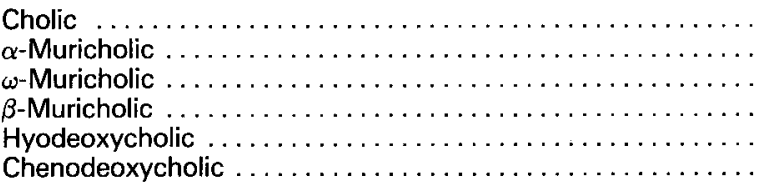 }} & $25.3 \pm 0.7$ & $1.7 \pm 0.1$ \\
\hline & & $3.8 \pm 0.1$ & $4.1 \pm 0.9$ \\
\hline & & - & $6.3 \pm 2.1$ \\
\hline & & $34.1 \pm 1.9$ & $2.6 \pm 0.7$ \\
\hline & & - & $26.8 \pm 3.5$ \\
\hline & & $2.6 \pm 0.3$ & $0.9 \pm 0.1$ \\
\hline \multirow{2}{*}{\multicolumn{2}{|c|}{$\begin{array}{l}\text { Deoxycholic } \ldots \ldots \ldots \ldots \ldots \ldots \ldots \ldots \ldots \ldots \ldots \ldots \ldots \ldots \ldots \ldots \ldots \ldots \ldots \ldots \ldots \ldots \\
\text { Ursodeoxycholic }\end{array}$}} & - & $13.7 \pm 0.8$ \\
\hline & & $1.8 \pm 0.1$ & $=$ \\
\hline \multicolumn{2}{|c|}{ 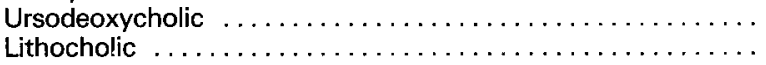 } & - & $9.2 \pm 0.2$ \\
\hline \multicolumn{2}{|c|}{ Keto } & - & $23.8 \pm 2.1$ \\
\hline \multicolumn{2}{|l|}{ Undetermined } & 32.4 & 10.8 \\
\hline
\end{tabular}

\section{TABLE 4}

Comparison by variance analysis of axenic and holoxenic rats fed a fiber-free or a $5 p .100$ pectin diet. $\mathrm{F}$ : flora action; $\mathrm{P}$ : pectin action ; $\mathrm{F} \times \mathrm{P}$ : interaction of $\mathrm{F}$ and $\mathrm{P}$;

NS ; non-singificant ; $\times p<0.05 ; \times x: p<0.01 ; \times x \times: p<0.005$

\begin{tabular}{|c|c|c|c|}
\hline Factors & $\mathrm{F}$ & $P$ & $F \times P$ \\
\hline Cecal weight $/ 100 \mathrm{~g}$ body weight & $x \times x$ & $x \times x$ & $x \times x$ \\
\hline Cecal water content (p. 100) & $x \times x$ & $x \times$ & $x \times x$ \\
\hline Absorption coefficient of cholesterol (6-7th d) & $x \times x$ & NS & NS \\
\hline Cholesterol concentration in plasma $\ldots \ldots \ldots$ & $\times$ & NS & $x$ \\
\hline Cholesterol concentration in liver ... & NS & $x$ & NS \\
\hline Fecal elimination of cholesterol .. & NS & NS & NS \\
\hline Fecal excretion of bile acids .. & $x$ & NS & NS \\
\hline Total fecal elimination of sterols & $x$ & NS & NS \\
\hline Total bile acid in the small intestine & $x \times x$ & NS & NS \\
\hline Total bile acid in the cecum and large intestine . & $x \times x$ & NS & $x$ \\
\hline
\end{tabular}

of these dietary fibers and their interaction with the digestive tract microbial flora. Table 4 summarizes the main results of the variance analysis applied to the GFO, GFP, CVO, CVP groups. With few exeptions the pectin caused little modification and only interacted rarely with the microbial flora. One of these exceptions was the effect on the cecum whose weight increased considerably in axenics and less in holoxenics, causing $F \times P$ interaction. This is opposed to the effect of bran which decreased cecal weight. Pectin modified cecal water content in opposite ways in axenics and holoxenics, but those variations were slight. It did not significantly change the cholesterol absorption coefficient whose value was measured on day 6-7, but, as did bran, it decreased the delay between unabsorbed cholesterol transit and that of $\beta$-sitosterol. The effects on plasma 
and hepatic cholesterol were very slight. There were no other significant variations in the metabolism of cholesterol and bile acids, except those of the cecum and large intestine bile acid pool, which increased in axenics and decreased slightly in holoxenics. Bran, on the contrary, decreased that pool by half in both groups of rats. Finally, pectin increased the percentage of cholic acid in the axenics (GFP $=25.3 \pm 0.7 ; \mathrm{GFO}=20.4 \pm 0.5 ; \mathrm{P}<0.005)$ to the detriment of $\beta$-muricholic acid (GFP $=34.1 \pm 1.9 ;$ GFO $=42.5 \pm 0.9$; $P<0.005)$. This effect is contrary to the one obtained when cholesterol is added into the diet (Sacquet et al., 1977) and could result from an interaction of pectin and dietary cholesterol.

Although pectin had few significant effects, it induced the abnormal variation of some characteristics (cecal weight, fecal cholesterol elimination, bile acid pool of cecum and large intestine, cholesterol conversion into coprostanol) in holoxenic rats. This variability was not found in either the axenics or in the other holoxenic rats, namely those receiving bran. Pectin would thus modify the effect of microbial activity on these characteristics in individuals in different ways and, even more so, in animal populations having different microbial flora, thus explaining the divergencies separating authors studying the effects of pectin.

The concentrations of plasma and hepatic cholesterol were, on the contrary, very homogeneous in GFP and CVP rats and little different from those of the GFO and CVO controls. This ineffectiveness of pectin, as opposed to all data in the literature, is difficult to explain, especially in the axenic rats. If pectin binds cholesterol and bile salts, as reported by some authors (Vahouny et al., 1980), the effect should be very clear when there is no microbial flora present to break it down. An alteration of pectin by gamma irradiation might have occured. This will be investigated in our laboratory.

Reçu en octobre 1981

Accepté en janvier 1982

Acknowledgements. - This work was supported by a DGRST grant ( $\mathrm{n}^{\circ} 80.7 .0117$ ) on Human Nutrition.

Résumé. Des rats axéniques et holoxéniques ingèrent un aliment semi-synthétique contenant 5 p. 100 de pectine comme unique fibre. Bien que la flore bactérienne du tractus digestif transforme dans une large mesure les acides biliaires chez les rats holoxéniques, elle modifie pəu les autres aspects du métabolisme du cholestérol et des acides biliaires à l'exception des contenus intestinaux en sels biliaires qui sont beaucoup plus grands chez les sujets axéniques.

La comparaison avec les rats qui reçoivent le même aliment dépourvu de fibre fait apparaître que la présence de pectine dans l'aliment augmente le poids du caecum, surtout chez les rats axéniques, mais modifie peu le métabolisme du cholestérol et des sels biliaires. Cependant, certaines caractéristiques de ce métabolisme ont des valeurs hétérogènes chez les rats holoxéniques qui ingèrent la pectine, alors qu'elles sont très homogènes chez les autres groupes de rats. Cette hétérogénéité pourrait provenir d'interactions entre la pectine et la flore microbienne du tractus digestif qui seraient variables d'un sujet à l'autre. 


\section{Références}

CROUSE, J. B., GRUNDY S. M., 1978. Evaluation of a continuous isotope feeding method for measurement of cholesterol absorption in man. J. Lipid Res., 19, 967-971.

GRUNDY S. M., AHRENS E. H., MIETTINEN T. A., 1965. Quantitative isolation and gas-liquid chromatographic analysis of total fecal bile acids. J. Lipid Res., 6, 397-410.

KELLEY J. J., TSAI A. C., 1978. Effect of pectin, gum arabic and agar on cholesterol absorption, synthesis and turnover in rats. J. Nutr., 108, 630.

LEVEILLE G. A., SAUBERLICH H. E., 1966. Mechanism of the cholesterol depressing effect of pectin in the cholesterol-fed rat. J. Nutr., 88, 207.

MATHÉ D., LUTTON C., RATUREAU J., COSTE T., GOUFFIER E., SULPICE J. C., CHEVALLIER F., 1977. Effects of dietary fiber and salt mixtures on the cholesterol metabolism of rats. J. Nutr., 107, 466-474.

REDDY B. S., WATANABE K., SHEINFIL A., 1980. Effect of dietary wheat bran, alfalfa, pectin and carrageenan on plasma cholesterol and fecal bile acid an neutral sterol excretion in rats. J. Nutr., 110, 1247-1254.

SACQUeT E., MEJEAN C., LEPRINCE C., RIOTTOT M., RAIBAUD P., 1977. Action du régime alimentaire et de la flore microbienne du tractus digestif sur le pool intestinal et l'excrétion fécale des acides biliaires chez le rat. Etude comparée chez des rats axéniques gnotoxéniques et holoxéniques. Ann. Nutr. Alim., 30, 603-617.

SACOUET E., LEPRINCE C., RIOTTOT M., 1982. Dietary fiber and cholesterol and bile acid metabolisms in axenic (germfree) and holoxenic (conventional) rats. I. Effect of wheat bran. Reprod. Nutr. Dévelop., 22, (in press).

VAHOUNY G. V., ROY T., GALLO T. T., STORY J. A., KRITCHEWSK D., CASSIDY M., 1980. Dietary fibers. III. Effects of chronic intake on cholesterol absorption and metabolism in the rat. Ann. J. clin. Nutr., 33, 2182-2191. 